\title{
EFFECT OF POWDERED SPICE TREATMENTS ON MYCELIAL GROWTH, SPORULATION AND PRODUCTION OF AFLATOXINS BY TOXIGENIC FUNGI ${ }^{1}$
}

\author{
Efeito de tratamentos com condimentos em pó sobre o crescimento micelial, \\ esporulação e produção de aflatoxinas por fungos toxigênicos
}

\author{
Sára Maria Chalfoun ${ }^{2}$, Marcelo Cláudio Pereira ${ }^{3}$, Mario Lúcio V. Resende ${ }^{4}$, \\ Caroline Lima Angélico ${ }^{5}$, Rozane Aparecida da Silva ${ }^{6}$
}

\begin{abstract}
The effect of ten powdered spice plants was evaluated at the concentration of 1,2,3 and $4 \%$ to observe the mycelial growth and sporulation of Aspergillus niger and Eurotium repens. The spices were added to the culture media PDA and CYA20S. Clove completely inhibited the mycelial growth of the tested fungi. The other spices: cinnamon, garlic, thyme, mint, anis, oregano and onion were, in a decreasing order, promising antifungals. Bay leaf and basil did not show a pronounced fungistatic effect. The antitoxigenic potential of the spices was tested against one aflatoxin-producing strain of AspergiIIus flavus. The spices were tested at the same concentrations previously mentioned and were added to the culture medium YES, appropriate for the production of those metabolites. Clove completely inhibited the mycelial growth of Aspergillus flavus. Cinnamon and anis totally inhibited the production of $\mathrm{B} 1$ and B2 aflatoxin. Both bay leaf and basil inhibited the synthesis of aflatoxin starting from the concentration of $2 \%$. The other spices did not have a pronounced antiaflatoxigenic effect.
\end{abstract}

Index terms: Spices, aflatoxins, control, fungi.

RESUMO

O efeito de dez plantas condimentares em pó foi avaliado nas concentrações de 1, 2, 3 e 4\%, para observar o desenvolvimento micelial e esporulação de Aspergillus niger e Eurotium repens. Os condimentos foram adicionados aos meios de cultura BDA e CYA 20S. O cravo inibiu completamente o desenvolvimento micelial dos fungos testados. Os outros condimentos: canela, alho, tomilho, menta, erva-doce, orégano e cebola foram, em ordem decrescente, antifúngicos promissores. Louro e manjericão não apresentaram um efeito fungistático pronunciado. O potencial antitoxigênico dos condimentos foi testado contra uma cepa de Aspergillus flavus, produtora de aflatoxina. Os condimentos foram testados nas mesmas concentrações previamente mencionadas e foram adicionados ao meio de cultura YES, apropriado para a produção daqueles metabólitos. O cravo inibiu completamente o desenvolvimento micelial do Aspergillus flavus. A canela e erva-doce inibiram totalmente a produção de aflatoxina B1 e B2. Louro e manjericão inibiram a síntese de aflatoxina a partir da concentração de $2 \%$. Os outros condimentos não apresentaram um efeito antiaflatoxigênico pronunciado.

Termos para indexação: Condimentos, aflatoxinas, controle, fungos.

(Recebido para publicação em 16 de abril de 2003 e aprovado em 8 de agosto de 2003)

\section{INTRODUCTION}

Powdered spice plants made into powder were widely used by ancient civilizations to improve the palatability of foods and beverages. The Egyptians took advantage of the preservative characteristics of these plants and the properties of essential oils of clove, cinnamon and cassis in the process of mummification of their dead. Equally, Greek and Roman literatures have many references of the use of these oils for medicinal purposes.

Several authors cited the antifungal and antitoxigenic activities of spices. (BULLERMAN, 1974; BULLERMAN et al., 1977; ARUN SHARMA et al., 1979; DEWIT et al., 1979; HITOKOTO et al., 1980; AZZOUS and BULLERMAN, 1982; FARAG et al., 1989).

\footnotetext{
1. Agricultural and Livestock Research Institution of Minas Gerais State - EPAMIG, P.O. Box 176 - 37200-000 - Lavras, MG, Brazil.

2. Researcher Dr./ Ecological Management Research Center of Pests and Diseases/EPAMIG, chalfoun@ufla.br

3. Fellow FAPEMIG.

4. Professor, Plant Pathology Department, Federal University of Lavras/UFLA - P.O. Box 37-37200-000 - Lavras, MG, Brazil.

5. Fellow CNP \& D/Café.

6. Doctorate student/UFLA.
} 
According to Farag et al. (1981), aflatoxins are hepatocarcinogenic, mutagenic, teratogenic, and toxic metabolites produced by fungi of the genus Aspergillus and Penicillium, which can develop in a variety of foods that are contaminated naturally, such as: cereals, almonds, dried fruits, milk, coffee and fruit juice. The quantity and the type of toxins produced are dependent on the chemical composition of the substract. (FARAG et al., 1989).

Bullerman et al. (1977) reported that raisin bread that had cinnamon in its composition, had both inhibited the development of Aspergillus parasiticus and the production of aflatoxin.

This study was carried out to determine the effect of the addition of powdered spices in culture media on the mycelial growth and sporulation of $A s$ pergillus niger and Eurotium repens and also on the production of toxins by Aspergillus flavus.

\section{MATERIAL AND METHODS}

The present work was developed at the Laboratory of Plant Pathology of EcoCentro/EPAMIG, campus of the Federal University of Lavras, Minas Gerais, Brazil.
Tests were performed with A. niger and $E$. repens, which are kept at the fungus collection of the Plant Pathology Laboratory of EPAMIG. A strain of $A$. flavus number 1011T02-01(EcoCentro), producer of aflatoxin, was also used in this work.

The inhibitory effect of ten powdered spices at the concentrations of $1,2,3$ and $4 \%$, was tested. The spices, offered by the SantosFlora Medicinal Herbs and Aromatics Enterprise, São Paulo-SP, were added to the culture media.

The spices listed in Table 1 were tested for their inhibitory effect on the development of fungi and for aflatoxin production, through "in vitro" tests.

The "in vitro" studies of the antifungal activities of powdered spices were done in culture media with the addition of a bactericide (cloranfenicol); PDA was used for A. niger and CYA+20S for E. repens (SAMSON et al., 1995). The spices were grinded to powder and added to $9 \mathrm{~cm}$ diameter Petri dishes, at concentrations above mentioned.

After seven days of incubation, ortogonal measurements were performed on the colonies' diameter by using the development of the control plates as a reference. Newbauer's chamber was used for counting spores.

TABLE 1 - Botanical classification and main active principles of the spices.

\begin{tabular}{llll}
\hline Common name & \multicolumn{1}{c}{ Scientific name } & \multicolumn{1}{c}{ Family } & \multicolumn{1}{c}{ Active principle } \\
\hline Garlic & Allium sativum $\mathrm{L}$. & Liliaceae & Allicin \\
Cinnamon & Cinnamomum burmannil Meissn & Lauraceae & Cynnamic aldehyde \\
Onion & Allium cepa $\mathrm{L}$. & Liliaceae & Thiopropanal-S-oxide \\
Clove & Caryophillus aromaticus $\mathrm{L}$. & Myrtaceae & Eugenol \\
Anis & Pimpinella anisum L. & Umbelliferae & Anetol \\
Mint & Mentha piperita $\mathrm{L}$. & Labiatae & Carvone \\
Bay leaf & Laurus nobilis $\mathrm{L}$. & Lauraceae & Cineol \\
Basil & Ocimum basilicum $\mathrm{L}$. & Lauraceae & Linalool \\
Oregano & Origanum vulgare $\mathrm{L}$. & Lamiaceae & Carvacrol \\
Thyme & Thymus vulgaris $\mathrm{L}$. & Labiatae & Thymol \\
\hline
\end{tabular}


The effect of powdered spices on the production of B1 and B2 aflatoxins by A. flavus was evaluated at ten-day-old cultures maintained in YES (yeast extract sucrose agar) medium at $25-26{ }^{\circ} \mathrm{C}$, through the agar plug method (FILTENBORG and FRISVAD, 1980).

The intensity of the blue fluorescence, characteristic of the production of B1 and B2 aflatoxins, was expressed by the symbols (+), adopted subjectively, giving those which showed more intense fluorescence the symbol $(+++)$; medium fluorescence $(++)$; low fluorescence (+) and (ND) to those which did not show the fluorescence.

A completely randomized experimental design was used with 3 replicates, with the factors arranged in a 9x2 (spice $x$ fungus) factorial scheme. Data analyses were carried out using the statistics package 'Analysis System of Modification for Balanced Data - Sisvar', according to Ferreira (2000). Means were compared by the Scott and Knott test. Spices which totally inhibited the mycelial growth did not take part in the statistics analyses.

\section{RESULTS AND DISCUSSION}

Inhibition of mycelial growth and sporulation of $A$. niger and $E$. repens were obtained with some of the spices tested. The level of inhibition was always proportional to the concentration used.

It was observed that clove and the cinnamon powders promoted total inhibition of $A$. niger mycelial development in all doses tested, which is in agreement with previous works (BACHAMANN, 1916; HITOKOTO et al., 1980; AZZOUS and BULLERMAN, 1982; BARA, 1992).

It can be observed in Figure 1 that the spices (garlic, anis, mint and thyme), showed indexes of varying inhibition according to the tested concentrations. However garlic powder inhibited the mycelial development from lower concentrations than thyme, anis and mint.

The tested spices, bay leaf, basil, oregano and onion did not show any significant inhibition of the mycelial development of the fungus.
When the inhibitory effect of the powdered spices on fungal sporulation was analyzed, the trend of progressive increase in the inhibition of sporulation with the increase of concentrations was also shown. These results agree with those obtained by Sharma et al. (1981), who observed an inhibitory effect of the lachrymatory factor (thiopropanalS-oxide) of onion to spores of A. parasiticus, proportional to the concentration and time of exposure.

It was also observed, according to the representation in Table 2, that garlic, mint, thyme, oregano and bay leaf showed the highest levels of sporulation inhibiton, followed by onion, basil and anis. All treatments reduced sporulation compared to the control treatment, where an average sporulation of $127,5 \times 10^{6}$ was found.

The inhibitory effect on sporulation is a fact that increases the efficacy of the treatments, since if the fungus has a certain degree of mycelial growth in the presence of spice treatments, the sporulation reduction has an additional impact on the fungus capacity of propagation. The evaluation of the efficacy of spice addition in relation to mycelial development of the fungus E. repens showed a total inhibition by clove powder at all tested doses.

High levels of fungal inhibition were observed for some spices, such as garlic and thyme. Cinnamon showed a trend to totally control the fungus at higher concentrations, while the poorest effects were observed for higher doses of mint and onion (Figure 2).

The spices bay leaf, oregano, and anis had no effect on the mycelial development of E. repens, when compared to the control treatment, which had a colony growth of $84 \%$ in relation to Petri dish diameter $(9 \mathrm{~cm})$.

Regarding the effect of spices on E. repens sporulation (Figure 3), it was verified that only cinnamon, thyme, bay leaf and oregano reduced sporulation, mainly at higher concentrations. Powdered onion and mint were unable to significantly inhibit the sporulation of the fungus. 


\section{$\square$ Garlic $\square$ Anis $\square$ Mint $\square$ Thyme}

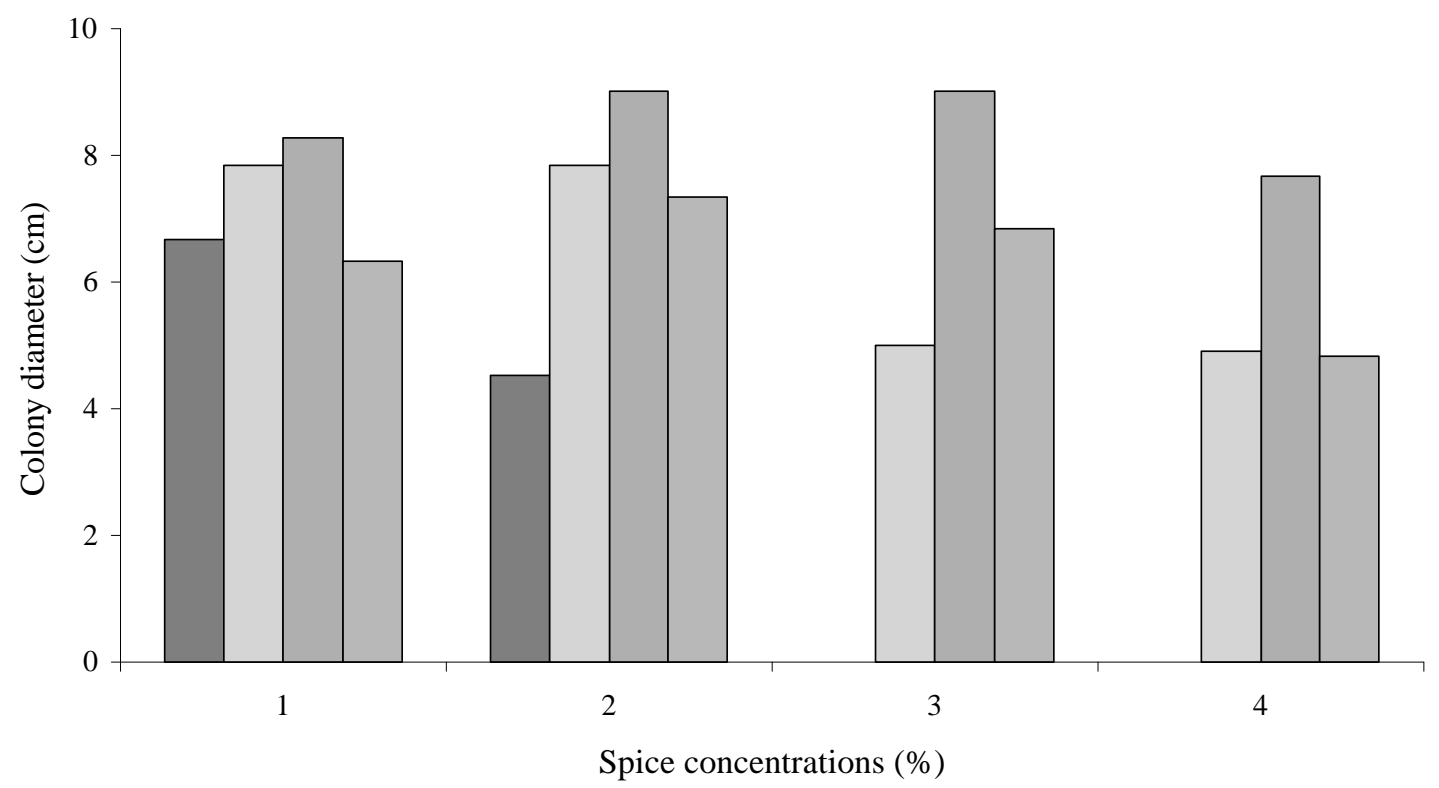

FIGURE 1 - Effect of the powdered spices concentrations on the mycelial development of the fungus A. niger.

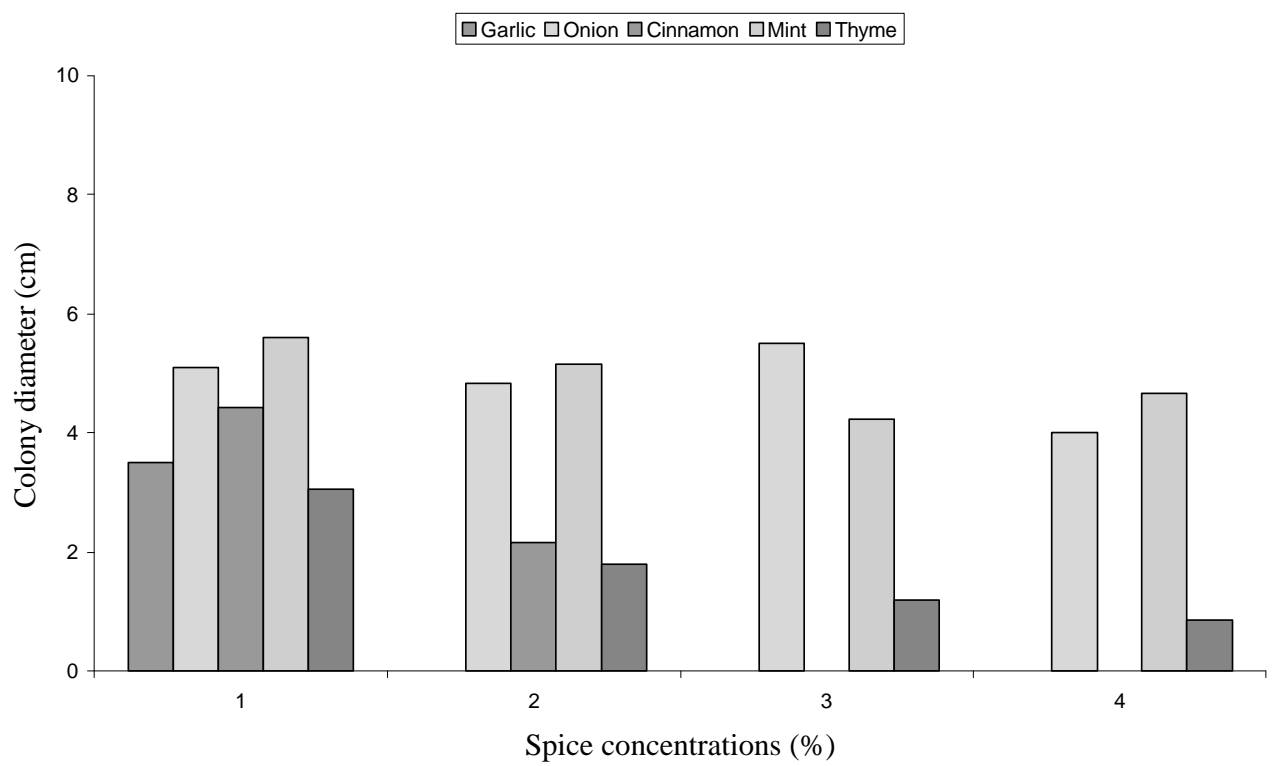

FIGURE 2 - Effect of the powdered spice concentrations on the mycelial development of E. repens. 


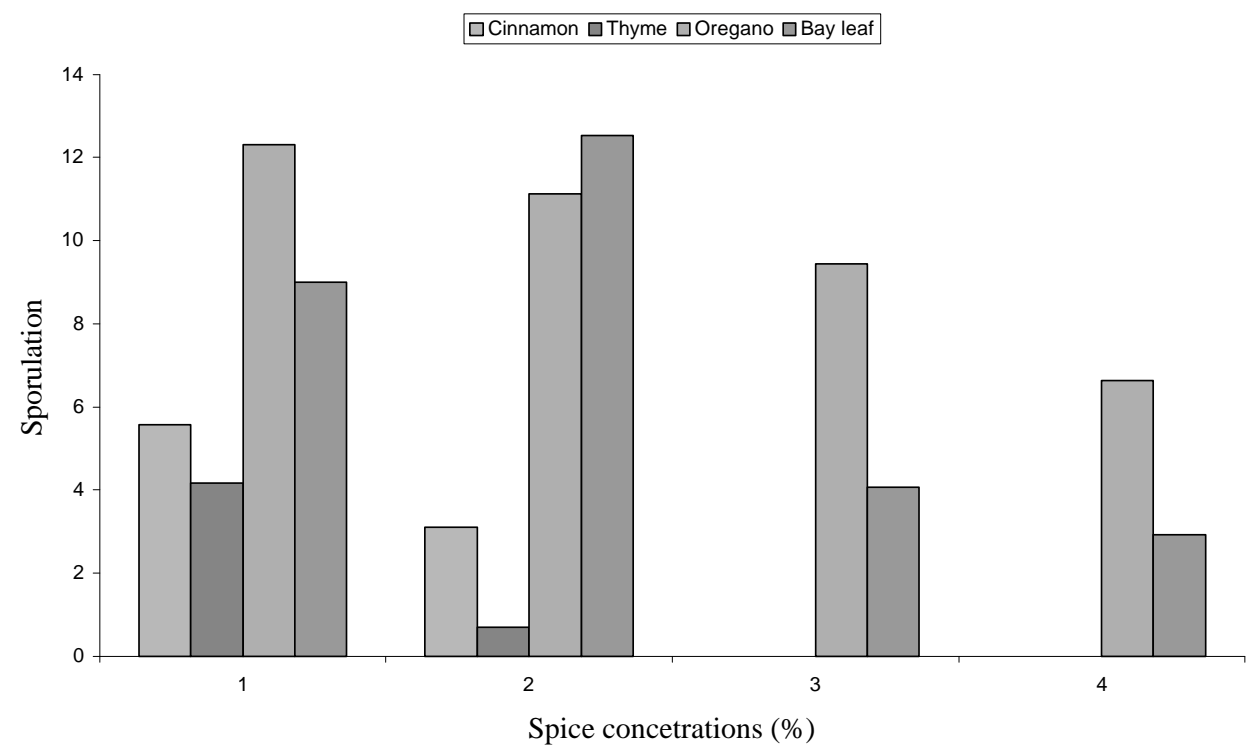

FIGURE 3 - Effect of the powdered spice concentrations on the sporulation of E. repens.

TABLE 2 - Effect of the powdered spice on the sporulation of A. niger.

\begin{tabular}{cc}
\hline Spices & Average sporulation* \\
\hline 1. Garlic & $1.35 \times 10^{6} \mathrm{a}$ \\
2. Onion & $5.8 \times 10^{6} \mathrm{~b}$ \\
3. Anis & $9.25 \times 10^{6} \mathrm{c}$ \\
4. Mint & $3.7 \times 10^{6} \mathrm{a}$ \\
5. Thyme & $2.9 \times 10^{6} \mathrm{a}$ \\
6. Oregano & $4.5 \times 10^{6} \mathrm{a}$ \\
7. Basil & $5.9 \times 10^{6} \mathrm{~b}$ \\
8.Bay leaf & $2.9 \times 10^{6} \mathrm{a}$ \\
\hline
\end{tabular}

*Means followed by the same letter are not significantly different by Scott and Knott test at $5 \%$ of probability.

Effect of the addition of powdered spices in relation to the production of aflatoxin

The development of A. flavus was totally inhibited by clove which supports the results previously obtained by Hitokoto et al. (1980), Azzous and Bullerman (1982) and Sinha et al. (1993), in relation to the effects of clove blocking the synthesis of the toxins.

It can be seen in Table 3, that anis and cinnamon completely inhibited the production of $\mathrm{B} 1$ aflatoxin (B1AF) and B2 aflatoxin (B2AF). Similar results were obtained by Tiwari et al. (1983), in which anis oil was used against the development and production of AFB1 by A. parasiticus and Patkar et al. (1983) using cinnamon against $A$. flavus.

Bay leaf promoted a total inhibition of B1AF and $\mathrm{B} 2 \mathrm{AF}$, starting from a concentration of $2 \%$ and basil showed a total inhibition of B2AF starting from concentration of $2 \%$ too. In relation to thyme a total inhibition of $\mathrm{B} 2 \mathrm{AF}$ was observed, while for $\mathrm{B} 1 \mathrm{AF}$, inhibition was only verified at the lowest concentration tested.

Both garlic and mint produced similar results in relation to the production of $\mathrm{B} 1 \mathrm{AF}$, with no evidence of a correlation between the tested concentrations and the inhibition of the toxin. In relation to B2AF, garlic completely inhibited it.

Regarding onion, the synthesis of both toxins occurred at all concentrations, although in a low intensity at the lowest $(1 \%)$ and in an intermediate concentration $(3 \%)$.

$\mathrm{B} 1 \mathrm{AF}$ and $\mathrm{B} 2 \mathrm{AF}$ were only inhibited by oregano at the highest concentration tested (4\%), since at lower concentrations (1, 2 and $3 \%$ ), fluorescence was more intense, similar to the pattern, indicating the higher production of toxin.

Based on results obtained, the use of some spices as an auxiliary treatment for the reduction of the mycelial development of A. flavus and the synthesis of the B1 and $\mathrm{B} 2$ aflatoxins, is recommended.

Ciênc. agrotec., Lavras, v. 28, n. 4, p. 856-862, jul./ago., 2004 
TABLE 3 - Results of the addition of spices on YES culture media in order to inhibit the production of aflatoxin using the Plug Agar technique.

\begin{tabular}{|c|c|c|c|c|c|c|c|c|c|c|}
\hline \multicolumn{11}{|c|}{ Treatments } \\
\hline \multirow{2}{*}{$\begin{array}{c}\text { Doses } \\
\%\end{array}$} & \multicolumn{2}{|c|}{ Thyme } & \multicolumn{2}{|c|}{ Garlic } & \multicolumn{2}{|c|}{ Cinnamon } & \multicolumn{2}{|c|}{ Oregano } & \multicolumn{2}{|c|}{ Bay leaf } \\
\hline & B1 & B2 & B1 & B2 & B1 & B2 & B1 & $\mathbf{B 2}$ & B1 & B2 \\
\hline 1 & ND & ND & + & ND & ND & ND & +++ & +++ & +++ & +++ \\
\hline 2 & +++ & ND & ND & ND & ND & $\mathrm{ND}$ & +++ & +++ & ND & ND \\
\hline 3 & +++ & ND & + & ND & ND & ND & +++ & +++ & ND & ND \\
\hline 4 & +++ & ND & ND & ND & ND & ND & $\mathrm{ND}$ & ND & ND & $\mathrm{ND}$ \\
\hline Doses & \multicolumn{2}{|c|}{ Basil } & & \multicolumn{2}{|c|}{ Mint } & \multicolumn{2}{|c|}{ Anis } & & \multicolumn{2}{|c|}{ Onion } \\
\hline$\%$ & B1 & B2 & & B1 & B2 & B1 & B2 & & B1 & B2 \\
\hline 1 & ++ & ++ & & ++ & ++ & $\mathrm{ND}$ & $\mathrm{ND}$ & & + & + \\
\hline 2 & + & $\mathrm{ND}$ & & +++ & +++ & ND & ND & & +++ & +++ \\
\hline 3 & ND & ND & & ND & ND & ND & ND & & + & + \\
\hline 4 & ND & ND & & +++ & +++ & ND & ND & & +++ & +++ \\
\hline
\end{tabular}

ND - Non Detected

+- Low Fluorescence

++- Medium Fluorescence

+++ - High Fluorescence

\section{CONCLUSIONS}

Clove powder at all the concentrations induced total inhibition of both studied fungi.

Cinnamon completely inhibited the development of A. niger, and at higher concentrations inhibited the mycelial development of E. repens. The production of $\mathrm{B} 1 \mathrm{AF}$ and $\mathrm{B} 2 \mathrm{AF}$ was totally inhibited at all concentrations of cinnamon and anis.

The other spices provided not so promising results, regarding the inhibition of mycelial growth, sporulation and toxin synthesis by the studied fungi.

\section{REFERENCES}

ARUN SHARMA, G. M.; TEWARI, A. J.; SHRIKHANDE, S. R.; PADWAL-DESAI; BANDYOPADHYAY, C. Inhibition of aflatoxinproducing fungi by onion extracts. Journal of Food Science, Chicago, v. 44, p. 1545-1547, 1979.
AZZOUS, M. A.; BULLERMAN, L. R. Comparative antimycotic effects of selected herbs, spices, plant components and commercial anti-fungal agents. Journal of Food Protection, Ames, v. 45, n. 14, p. 1298-1301, 1982.

BACHAMANN, F. M. The inhibiting action of certain spices on the growth of microorganisms. Journal of Industrial and Engineering Chemistry, Easton, n. 8, p. $620-623,1916$.

BARA, M. T. F. Avaliação do efeito inibidor de condimentos no desenvolvimento de Yersinia enterocolitica. 1992. 73 f. Dissertação (Mestrado em Microbiologia Agrícola) - Universidade Federal de Viçosa, Viçosa, 1992.

BULLERMAN, L. B. Inhibition of aflatoxin production by cinnamon. Journal of Food Science, Chicago, v. 39, n. 6, p. 1163-1165, Nov./Dec. 1974. 
BULLERMAN, L. B.; LIEW, F. Y.; SEIER, S. A. Inhibition of growth and aflatoxin production by cinnamon and clove oils, cinnamic aldehyde and eugenol. Journal of Food Science, Chicago, n. 42, n. 6, p. 1107-1109, Nov./Dec. 1977.

DEWIT, J. C.; NOTERMANS, S.; GORIN, N.; KAMPELMACHER, E. H. Effects of garlic and onion oil on toxin production by Crostridium botulinum in meat slurry. Journal of Food Protection, Ames, v. 42, p. 222-224, 1979.

FARAG, R. S.; DAW, Z. Y.; ABO-RAYA, S. H. Influence of some spice essencial oils on Aspergillus parasiticus growth and production of aflatoxinas in a synthetic medium. Journal of Food Science, Chicago, v. 54, n. 1, p. 54-74, Jan./Feb. 1989.

FARAG, R. S.; KHALIL, F. A.; TAHA, R. A.; ABOULENIEN, A. Chemical studies on the unsaponifiable matter of the cottonseed and peanut oils infected by Aspergillus flavus. Grasas Y Aceites, Seville, v. 32, p. 87, 1981.

FERREIRA, D. F. Análise estatística por meio do Sisvar para Windows: versão 4.0 In: REUNIÃO ANUAL DA REGIÃO BRASILEIRA DA SOCIEDADE INTERNACIONAL DE BIOMETRIA, 45., 2000, São Paulo, SP. Anais... São Paulo: SIB, 2000. p. 255-258.

FILTENBORG, O.; FRISVAD, J. C. A simple screening: method for toxigenic moulds in pure cultures. Lebensmittel Wissenschaft und Technologie, London, v. 13, p. 128-130, 1980.
HITOKOTO, H.; MOROZUMI, S.; WAUKE, T.; SAKAI, S.; KURATA, H. Inhibitory effects of spices on growth and toxin production of toxigenic fungi. Tokyo. Applied and Environmental Microbiology, Washington, v. 39, n. 4, p. 818-822, Apr. 1980.

PATIKAR, K. L.; USHA, C. M.; SHETTY, H. S.; PASTER, N.; LACEY, J. Effect of spice oils growth and aflatoxin B1 production by Aspergillus flavus. Letters in Applied Microbiology, Oxford, v. 17, p. 49-51, 1993.

SAMSON, R. A.; HOEKSTRA, E. S.; FRISVAD, J. C.; FILTENBORG, O. Introdution to food-borne fungi. 4. ed. [S.1.]: Centraalbureau Voor Schimmelcultures Baarn Delft, 1995. 322 p.

SHARMA, A.; PADWALL-DESAI, S. R.; TEWARI, G. W.; BANDYOPADHYAY, C. Factors affecting antifungal activity of onion extractives against aflatoxin producing fungi. Applied and Environmental Microbiology, Washington, v. 46, n. 3, p. 741-744, 1981.

SINHA, K. K.; SINHA, A. K.; GAJENDRA, P. The effect of clove and cinnamon oils on growth of and aflatoxin production by Aspergillus flavus. Letters in Applied Microbiology, Oxford, v. 16, p. 114-117, 1993.

TIWARI, R.; DIKSHIT, R. P.; CHANDAN, N. Inhibition of growth and aflatoxin B1 production of Aspergillus parasiticus by spice. Journal of Food Science an Tecnology, India, v. 20, p. 131-132, 1983. 